\begin{abstract}
Iranica
Abstracta Iranica Revue bibliographique pour le domaine irano-aryen

Volume 34-35-36 | 2017

Comptes rendus des publications de 2011-2013
\end{abstract}

\title{
R. Boucharlat. Southwestern Iran in the Achaemenid period
}

\section{Astrid Nunn}

\section{(2) OpenEdition}

Journals

Édition électronique

URL : http://journals.openedition.org/abstractairanica/41678

DOI : 10.4000/abstractairanica.41678

ISSN : 1961-960X

Éditeur :

CNRS (UMR 7528 Mondes iraniens et indiens), Éditions de l'IFRI

Référence électronique

Astrid Nunn, «R. Boucharlat. Southwestern Iran in the Achaemenid period», Abstracta Iranica [En ligne], Volume 34-35-36 | 2017, document 80, mis en ligne le 15 juillet 2016, consulté le 02 octobre 2020. URL : http://journals.openedition.org/abstractairanica/41678; DOI : https://doi.org/10.4000/ abstractairanica.41678

Ce document a été généré automatiquement le 2 octobre 2020.

Tous droits réservés 


\title{
R. Boucharlat. Southwestern Iran in the Achaemenid period
}

\author{
Astrid Nunn
}

\section{RÉFÉRENCE}

R. Boucharlat. "Southwestern Iran in the Achaemenid period », in: D.T. Potts, éd., The Oxford Handbook of Ancient Iran. New York, Oxford University Press, 2013, p. 503-527.

1 Le Fārs, région mère et phare de l'Empire achéménide, est présentée par l'archéologue R.B. qui y a travaillé pendant des décennies. Sa présentation, ordonnée chronologiquement, débute par le site de Pasargades en y englobant les derniers résultats obtenus lors de prospections (cf. ARTA 2012.003). Suivent Persépolis, Naqš-e Rostam et Suse, sites tous liés à Darius I. Les informations subséquentes sont d'ordre général et concernent les résidences royales, les routes, les sanctuaires et les pratiques funéraires.

\section{AUTEURS}

\section{ASTRID NUNN}

Université de Munich 